\title{
Substitution of Cow's Milk for Milk of Lupinus Mutabilis in the Production of Fresh Cheese
}

\author{
Cortez, A ${ }^{1}$, Ruíz, $\mathbf{H}^{2}$, Torres, $\mathbf{R}^{3}$ \\ ${ }^{1}$ Universidad Técnica Estatal de Quevedo, Quevedo, Ecuador \\ ${ }^{2}$ Escuela Superior Politécnica de Chimborazo, Chimborazo, Ecuador \\ ${ }^{3}$ Universidad Técnica Estatal de Quevedo, Quevedo, Ecuador
}

\begin{abstract}
This research was carried out in the ESPOCH, of an observational and experimental type in the elaboration of fresh cheese, partially replacing the cow's milk with the milk of Lupinus mutabilis to balance the lactose content, obtaining that the T1 treatment is the most accepted because it possesses The characteristics similar to traditional fresh cheese, with a degree of acceptability of consumption in people intolerable to lactose; Increases milk levels of pips is decreasing fat, protein and lactose, the amount of microorganisms are below the limit allowed, with proper management of hygiene. The study started with four treatments of Lupinus mutabilis milk (0,10,20, 30 and 40\%) and four replicates, 100 it of cow's milk, divided 5 lt for each experimental unit, in 40\%, no No cheese or results were obtained. In this way it contributes to scientific research with the use of products from Ecuador, whose milk is little used because of the lack of knowledge about the nutritional contribution it provides to the human organism.
\end{abstract}

Keywords: Milk, cow, Lupinus mutabilis, fresh cheese

\section{Introduction}

In our country more and more people are suffering from lactose intolerance due to the scope and the situation of life regime, so food professionals should look for alternative foods that include in their diets so that their health is not affected And above all provides nutritional benefits; Since these people, who are sometimes unaware of or are aware of, do not find products that partially or totally substitute dairy products derived from cow's milk, which in their composition contain lactose and lactose, which causes them stomach disorders, Presenting difficulty in absorbing and unfolding it; So they are forced to stop consuming them and in the food pyramid the intake of dairy is very important for the health of the human being.

The use of milk from Lupinus mutabilis is widely used for dairy processing has become a healthy alternative for the consumption of people who are intolerable to lactose from cow's milk, as it provides certain essential amino acids that the body does not Is able to synthesize by itself. Among the products that are made on the basis of milk of Lupinus mutabilis is the cheese, which contains a high protein concentration.

This research was carried out at the Polytechnic School of Chimborazo, is observational and experimental in the production of fresh cheese, partially substituting cow's milk and using milk from Lupinus mutabilis to balance the lactose content, determining its organoleptic characteristics ( Color, odor, texture, taste and appearance); (Fat, carbohydrates, protein and lactose); (Coliforms, Escherichia coli, molds and fungi) and their degree of acceptability of consumption in people intolerable to lactose, promoting consumption alternatives that contain essential nutrients to the body.
In this way, it contributes to solve food problems presented by society today, contributing to scientific research with the use of products from Ecuador such as Lupinus mutabilis, whose milk is little used because of the lack of knowledge about the nutritional contribution It provides to the organism of the human being.

\section{Importance}

The present investigation had the firm purpose of determining the effect of the substitution of milk from Lupinus mutabilis milk on the content of fresh cheese, since it was possible to create an innovative product that would benefit the Are intolerable to lactose and contain the same nutritional components of cow's milk, cow's milk is not going to be completely replaced because we need a product containing casein to facilitate precipitation during the production of fresh cheese and thus Combine it with a product of vegetable origin, whose nutritional result will be a product with high protein content.

And it is beneficial for people, not to stop consuming dairy products, and also have alternatives to consumption of products derived from puff, finally with the help of industry and analysis of the finished product is guaranteed, get a product Therefore, it is considered necessary to carry out this research work.

This work will be very important, since it will contribute with new alternatives of consumption of dairy products, not those that we are accustomed to the consumers, but with the substitution of a vegetal milk with nutritional characteristics, in addition that will obtain an economic and profitable product, for Reach an attractive end product for the local market. 


\section{International Journal of Science and Research (IJSR) \\ ISSN (Online): 2319-7064 \\ Index Copernicus Value (2015): 78.96 Impact Factor (2015): 6.391}

\section{Methodology}

The development of the research focused on the effect of partially replacing cow's milk with Lupinus mutabilis milk in order to reduce the lactose content of traditional fresh cheese in order to reduce the intolerance of consumers to lactose by contributing to An alternative and quality product.

In the research, 100 liters of milk were used, each experimental unit was conformed by $5 \mathrm{lt}$, having four treatments in which different levels of milk of Lupinus mutabilis plus one control and four replications were used, therefore we worked with 20 experimental units . That is, 3 levels of milk of Lupinus mutabilis were evaluated in substitution of cow's milk in the elaboration of fresh cheese versus a control treatment, the experimental units were distributed, under a completely random design, adjusted to the following linear additive model. $\mathrm{Y}=\mathrm{U}+\mathrm{Ti}+$ Eij. Where:

$\mathrm{Yi}=$ Estimated value of the dependent variable. $\mathrm{U}=$ Value of the general mean. $\mathrm{Ti}=$ Effect of treatments (milk levels of Lupinus mutabilis). Eij $=$ Experimental error.

Modality and Type of Research The basis of this research was experimental, to verify data and to know exactly the manifestation of lactose content by partially replacing cow's milk with Lupinus mutabilis milk within the Dairy Processing laboratory. Variables The variables considered in the present investigation are the following: Independent variable: Percentages of milk of Lupinus mutabilis $(10,20,30$ and $40 \%)$

\section{Dependent Variables:}

\section{a. Bromatological \\ Protein \\ Lipids \\ Carbohydrates \\ Lactose}

\section{b. Sensory \\ Color, dots. \\ Smell, dots \\ Taste points \\ Texture, dots \\ Total valuation, points.}

\section{c. Microbiological \\ Content of mesophilic aerobes UFC / g. \\ Contents of Moldy and Yeast UFC / g. \\ Content of echerichia coli UFC / $\mathrm{g}$}

\section{Sampling}

The sensory analysis information was performed by tasting tests to a population intolerant to lactose in different sessions to establish the best treatment and guarantee a product of quality and harmless to the consumer.

Subsequently, a sampling technique was used to perform the bromatological analyzes, which were sent to the Technological Transfer Center (CESTA) of the Faculty of
Livestock Sciences of ESPOCH, in the city of Riobamba, according to the protocols of sampling and Lab labeling, which indicated 100 grams of sample for each analysis and repetition was consequently applied observation and experimentation in different laboratories, with statistical analyzes was obtained checking the hypothesis

\section{Techniques}

The scientific observation allowed to know the reality through the direct perception of the behavior of the milk of Lupinus mutabilis in the content of the fresh cheese, that is to say in what percentage the product is acceptable. During the elaboration process, by scientific observation, it was possible to measure the effect of the substitution of cow's milk for the milk of Lupinus mutabilis by checking the hypotheses proposed, in addition the periodic increase of milk Lupinus mutabilis was observed to see its effect in the lactose and protein content of fresh cheese.

Tasting tests: It was done with people with lactose intolerance, during the tasting they filled a set of closed questions and the information was collected.

\section{Elaboration of Lupinus Mutabilis Cheese \\ Equipment \\ Pot \\ Molding Table \\ Press \\ Sealer}

\section{Materials}

Measuring jug

A liencillo to filter the product.

$25 \mathrm{~cm} \times 25$ piece paper.

Stainless steel molds for cheese.

Cured wood blocks.

Lira, spoons, knives

Surgical Gloves and Mask

Plastic Cases

\section{Milk of Lupinus mutabilis}

To obtain the milk of Lupinus mutabilis proceeded as follows:

1) Grind 3 kilos of Lupinus mutabilis in a mill.

2) Pass through a bag of liencillo and press hard to get the milk, with the help of surgical gloves.

3) Repeat this process until the entire product is finished.

4) Bring to a water bath on a low heat for 10 minutes. To remove constantly.

\section{Chemical analysis}

The bromatological analyzes corresponding to: Protein, Carbohydrates, Fat and lactose:

Determination of Protein

For determination of Protein $\%$ is based on the standard for fresh cheese NTE INEN 1528: 2012.

For determination of the protein was subjected to heating and digestion of the sample with concentrated sulfuric acid, carbohydrates and fats were destroyed to form $\mathrm{CO} 2$ and water, the protein disintegrated with the formation of

Volume 6 Issue 1, January 2017 


\section{International Journal of Science and Research (IJSR) \\ ISSN (Online): 2319-7064 \\ Index Copernicus Value (2015): 78.96 Impact Factor (2015): 6.391}

ammonia, which intervenes in the Reaction with sulfuric acid to form ammonium sulfate. The calculation was made with the following formula:

$$
\% \mathrm{~PB}=\frac{\mathrm{NHCl} 9 * \mathrm{mlHCl} * 0.014 * 100 * \mathrm{ml} * 6.25}{m l \text { de muestra }}
$$

Where:

NHCL: normality of hydrochloric acid. Ml HCl: volume of aq. Hydrochloric. $0.014=$ milliliters of nitrogen equivalent $6.25=$ conversion factor.

$\mathrm{ml}=$ sample volume

\section{Determination of fat:}

For determination of Fat $\%$ is based on the norm for fresh cheese INEN 64 1973-10. The ether was evaporated and continuously condensed, the soluble materials being extracted through the sample. The extract was collected in a beaker, the ether was distilled and collected in another vessel, the crude fat remained in the vessel, dried and weight controlled. The calculation was made with the following formula:

$$
\% \mathrm{EE}=\frac{M 1-M 2}{W} \times 100
$$

Where:

$\mathrm{EE}=$ amount of fat in percentage of mass

$\mathrm{M}=$ mass of the extraction vessel with the fat extracted in grams.

M2 = mass of the extraction vessel, vacuum in grams. $\mathrm{W}=$ mass of the sample in grams.

3.1.11.3. Lactose: For the determination of $\%$ Lactose is based on the standard for fresh cheese INEN - 65

\section{Procedure and materials:}

Reducing sugars: When a reducing sugar solution with an equal volume of the Fehling liquor is heated by mixing in boiling water, the cupric salt is reduced to red cuprous oxide. The reaction is positive for lactose and maltose.

As well as for monosaccharides. Sucrose also produces a precipitate if the solution has been previously hydrolyzed to glucose and fructose by means of acid heating. Reducing sugars also form a silver mirror when heated with silver ammonium solutions. Copper Reduction Methods: Sugars that have free aldehydes or ketones in their structure react as weak reducing agents and are called reducing sugars. These include all monosaccharides and disaccharides maltose, lactose and cellobiose. Fehling's liquor consists of alkaline cupric tartrate and is converted into insoluble cuprous oxide upon boiling with a solution of the reducing sugar. This forms the basis of certain procedures.

\section{Microbiological analysis:}

The microbiological analysis was performed based on INEN 1528 standards, which was developed in private laboratories CETLAP (Technological Transfer Center and Agricultural Laboratories), whose results were certified.

Microbiological requirements of cheese, Requirements Unit Maximum Test method Echerichia Coli Colonies / g 100 INEN 1529

Etaphilococcus Aureus Colonies / g 100 INEN 1529
Molds and yeasts Colonies / g 50,000 INEN 1529

Salmonella Colonies / 25 g 0 INEN 1519

Source: Standard INEN 1528.

\section{Determination of organoleptic characteristics and degree} of preference

The organoleptic characteristics were determined with panelists from the Career of Agroindustrial Engineering of the National University of Chimborazo. The same were 5 teachers (trained tasters) and 30 students from the fourth semester of the same institution (untrained tasters).

Trying in great measure, respectively, to give the most transparent possible to obtain favorable and accurate results so that the following rules were applied.

The taster both trained and untrained must:

- The place where the tasting is to take place should have sufficient light.

- Have not smoked for at least 3 hours before the tasting.

- Do not contain chewing gum, candy or any kind of food that prevents you from tasting it.

- The taster before and after ingesting the product should rinse his mouth with water to avoid confusion in the characteristics of the product and take intervals of at least 10 minutes to proceed with the next tasting.

The 35 panelists or tasters were given a sample of each product in pre-sealed plastic containers and listed:

$1=$ for the control cheese with $0 \%$ milk of Lupinus mutabilis.

2.- cheese with $10 \%$ milk of Lupinus mutabilis

3.- cheese with $20 \%$ milk of Lupinus mutabilis

4.- cheese with $30 \%$ milk of Lupinus mutabilis

They were also given a glass of water and sheets containing 2 tables one to qualify the organoleptic characteristics of the product (color, smell, taste, texture and appearance).

\section{Experimental Design}

To perform the evaluation of the bromatological, microbiological and sensorial characteristics of Lupinus mutabilis cheese, the experimental results were modeled under a Completely Random Design (DCA). Analysis of variance (ADEVA), for the different bromatological variables.

Comparison of means by Duncan $(\mathrm{P}<0.05)$, for the different microbiological variables.

Kruskal-Wallis test, for sensory variables. The Kruskall Wallis test was used to determine the significance of the sensory variables.

Table 1: Scheme of the experiment

\begin{tabular}{|c|c|c|c|c|}
\hline $\begin{array}{c}\text { Levels of Lupinus } \\
\text { Mutabilis Milk }\end{array}$ & Códe & Repet. & T.UE & $\begin{array}{c}\text { Lupinus Mutabilis } \\
\text { Milk / Treatment }\end{array}$ \\
\hline $0 \%$ & T0 & 4 & 5 & 20 \\
\hline $10 \%$ & T1 & 4 & 5 & 20 \\
\hline $20 \%$ & T2 & 4 & 5 & 20 \\
\hline $30 \%$ & T3 & 4 & 5 & 20 \\
\hline $40 \%$ & T4 & 4 & 5 & 20 \\
\hline \multicolumn{2}{|c|}{ Total liters of milk } & & 100 \\
\hline
\end{tabular}

Volume 6 Issue 1, January 2017 


\section{International Journal of Science and Research (IJSR) \\ ISSN (Online): 2319-7064 \\ Index Copernicus Value (2015): 78.96 Impact Factor (2015): 6.391}

\section{Population and Sample}

The population is established by the total of the production in each repetition of the test and the sample was of $200 \mathrm{~g}$ of each experimental unit, which were identified and labeled; And sent to the Laboratory of Chemical Sciences of FCP $\mathrm{ESPOCH}$, for the determination of nutritional and microbiological content.

For the organoleptic tests were formed teams of 4 people, per session, the panel met certain rules as strict individuality among panelists to avoid influences between them, not having ingested alcoholic beverages and dispose by hand water or tea, to Equalize the senses.

In the evaluation of organoleptic characteristics the following procedure was followed:

Each taster was presented with four different samples per session and all tasters tasted all treatments in one session for each block before a random draw of treatments within each block.

Once the samples of the treatments to be evaluated during the session were defined, the sensorial evaluation was carried out, for which each panelist was given the corresponding survey in which the samples were evaluated on a numerical scale, according to the scale Preset. This process was repeated in each session, with all the results obtained, we proceeded to the statistical evaluation according to the Test of Ranking Test (Witting 2001). And finally the economic analysis was evaluated using the cost benefit indicator.

Table 2: Experiment formula

\begin{tabular}{|c|c|c|c|c|c|}
\hline & \multicolumn{5}{|c|}{ Milk levels of Lupinus mutabilis } \\
\hline Raw material & Uni & $0 \%$ & $10 \%$ & $20 \%$ & $30 \%$ \\
\hline Pasteurized Milk & lt & 20,0 & 16,0 & 12,0 & 8,0 \\
\hline Leche de Lupinus mutabilis & lt & 0,0 & 4,0 & 8,0 & 12,0 \\
\hline Liquid rennet & $\mathrm{ml}$ & 2,0 & 2,0 & 2,0 & 2,0 \\
\hline Calcium chloride & $\mathrm{g}$ & 5,0 & 5,0 & 5,0 & 5,0 \\
\hline Salt & $\mathrm{g}$ & 250,0 & 250,0 & 250,0 & 250,0 \\
\hline
\end{tabular}

\section{Results}

\section{Bromatological analysis}

\section{Fat Content}

The fat content studied in samples of fresh cheese made with Lupinus mutabilis milk shows statistically highly significant differences, the highest fat content in the control treatment with a value of $5.13 \%$ in the lowest fat value is $3.19 \%$ In the treatment that I used $30 \%$ of milk of Lupinus mutabilis, $4.06 \%$ the treatment that I used $20 \%$ of milk of Lupinus mutabilis, and reaches up to $4.54 \%$ of fat in the treatment that I use $10 \%$ of milk of Lupinus mutabilis this Is due to the fact that Lupinus mutabilis does not have fat in considerable amounts to influence the nutritive constitution of the fresh cheese.
When analyzing the carbohydrate content in the study samples it can be determined that there is a statistical difference especially between the control treatment with the lowest value being $2.95 \%$ and the T3 treatment that is the one that used $30 \%$ of Lupinus milk Mutabilis in the making of fresh cheese obtained the highest amount of carbohydrates $3.94 \%$ respectively

\section{Protein Content}

As for the protein evaluation of fresh cheese, it is possible to determine that there is a highly significant statistical difference obtaining the highest value in the control treatment of $15.33 \%$ and as milk levels of Lupinus mutabilis increase, the protein values in the Thus, in the T1 treatment that used $10 \%$ of milk of Lupinus mutabilis obtained $14.19 \%$ of protein, in treatment T2 that used $20 \%$ of milk of Lupinus mutabilis obtained a value of $12.58 \%$ and in the treatment $\mathrm{T} 3$ that Used 30\% milk Lupinus mutabilis obtained the lowest protein value which was $10.66 \%$.

\section{Lactose content}

The lactose content decreased as Lupinus mutabilis milk levels increased and the highest value in the control treatment T0 of $3.68 \%$ was observed, and the lowest value was found in the T3 treatment that used $30 \%$ milk from Lupinus mutabilis $2.06 \%$ respectively.

\section{Microbiologic Analysis}

The positive cases found in the samples of fresh cheeses obtained have microorganisms but are within the limits allowed

It is possible to appreciate the presence of mesophilic aerobes at 7 days of cheeses, there are statistical differences between treatments so that it is possible to see that the greatest number of microorganisms has the $\mathrm{T} 1$ treatment, which uses $10 \%$ of milk of Lupinus mutabilis and The lowest amount of microorganisms obtained the T3 treatment that was performed with $30 \%$ milk of Lupinus mutabilis, the statistical differences are maintained when analyzing the microorganisms at 14 days, it is very logical to observe this result because the analyzed samples were taken from The same cheeses and preserved for different time, it should be emphasized that the amount of microorganisms found are below the limit allowed according to the Maximum Permissible Limits For Milk Products Microbiological NOM-243-SSA1-2010, As the amount of Lupinus mutabilis milk increases, the decrease in microorganisms is evidenced. This is because Lupinus mutabilis has alkaloids and these act as antimicrobial agents (Villacres, et al., 2009).

In the analysis of molds and yeasts can be observed the existence in the samples analyzed and that like the mesophilic aerobes are in an amount allowed by the MAXIMUM LIMITS PERMISSIBLE FOR MICROBIOLOGICAL DAIRY PRODUCTS NOM-243SSA1-2010.

\section{Carbohydrate Content}

\section{Volume 6 Issue 1, January 2017 www.ijsr.net}




\section{International Journal of Science and Research (IJSR) \\ ISSN (Online): 2319-7064 \\ Index Copernicus Value (2015): 78.96 | Impact Factor (2015): 6.391}

\begin{tabular}{|c|c|c|c|c|c|c|c|c|c|c|c|c|}
\hline \multirow[b]{2}{*}{ settings } & \multicolumn{8}{|c|}{ Milk levels of Lupinus mutabilis } & \multirow[b]{2}{*}{ C.V } & \multirow[b]{2}{*}{ E. Estand. } & \multirow[b]{2}{*}{ Prob. } & \multirow[b]{2}{*}{ Sig } \\
\hline & $0,0 \%$ & & $10 \%$ & & $20 \%$ & & $30 \%$ & & & & & \\
\hline Aerobios mesófilos 7 días & 110 & $\mathrm{a}$ & 121,75 & $\mathrm{~b}$ & 117,00 & $\mathrm{~b}$ & 109,50 & $\mathrm{a}$ & 3,3 & 14,313 & 0,0016 & $* *$ \\
\hline Aerobios mesófilos 14 días & 120 & $\mathrm{~b}$ & 133,00 & $\mathrm{c}$ & 121,75 & $\mathrm{~b}$ & 112,25 & $\mathrm{a}$ & 3,80 & 21,458 & 0,0004 & $* *$ \\
\hline Mohos levaduras 7 días & 18 & $\mathrm{a}$ & 21,50 & $\mathrm{~b}$ & 18,50 & $a b$ & 21,25 & $\mathrm{~b}$ & 9,53 & 3,563 & 0,042 & $*$ \\
\hline Mohos levaduras 14 días & 21 & $\mathrm{a}$ & 26,00 & $\mathrm{~b}$ & 23,75 & $a b$ & 21,50 & $\mathrm{a}$ & 8,28 & 3,646 & 0,0111 & $*$ \\
\hline Eschericha coli & ausencia & & ausencia & & ausencia & & ausencia & & & & & \\
\hline \multicolumn{13}{|c|}{ E. Estand.: Standard error, ${ }^{* *}$ Highly significant statistical difference, ${ }^{*}$ Significant statistical difference } \\
\hline \multicolumn{13}{|c|}{$\mathrm{P}>0.05$, There are no statistical differences according to ADEVA } \\
\hline Source: Cristina, C. (2015) & & & & & & & & & & & & \\
\hline
\end{tabular}

\section{Organoleptic Analysis}

The samples were analyzed by panelists in the Ranking Test, the results obtained were submitted to the Kruskal-Wallis test, a statistical test that is used for non-parametric samples whose results are detailed below.

\section{Odor analysis}

Since odor is one of the most important factors in a food and especially of fresh cheese is determined after the panelists' assessment in the test of test ranking and analyzed statistically with the test Kruskal-Wallis determined that there is a statistical difference between The treatments analyzed, the best score obtained the T0 with the rating of 3.5 / 5 the treatments that used milk of Lupinus mutabilis maintained a similar rating of 2.00 to $2.13 / 5$ points. That is because we are accustomed to the smell of fresh cheese and also Lupinus mutabilis possesses its characteristic odor that is associated with the smell of traditional fresh cheese.

\section{Color Analysis}

Regarding the color evaluation, no statistical differences were observed between the analyzed treatments, the color of the fresh cheese and the cheeses with milk of Lupinus mutabilis have similar coloration.

\section{Taste Analysis}

The taste analyzed in this research did not show statistical differences between the treatments maintained an equal score of $3 / 5$ points between the treatments $\mathrm{T} 0$ and $\mathrm{T} 1$, a score of
2.5 / 5 was observed in the treatment T2 that used $20 \%$ of milk of Lupinus Mutabilis, and a score of 2.75 / 5 obtained the T3 treatment that was the treatment that used $30 \%$ of milk of Lupinus mutabilis in the elaboration of the fresh cheese.

\section{Texture analysis}

As for the texture of the fresh cheese statistically no significant difference was found but if there is a numerical difference, it was determined that the T3 treatment that used $30 \%$ of milk of Lupinus mutabilis in the elaboration of the fresh cheese obtained a score of 2.5 / 5 and the highest score obtained the T2 treatment that used $20 \%$ of milk of Lupinus mutabilis in its elaboration.

\section{Analysis of acidity}

The acidity was another of the values that did not present statistical differences, because the conditions of elaboration allowed to obtain a fresh product in good conditions, the milk of Lupinus mutabilis is not easily acidified because it has characteristics very similar to those of the Cow milk.

\section{Appearance Analysis}

As regards the aspect of the fresh cheese analyzed in this research, statistical differences between the treatments $\mathrm{T} 0$, T3 vs T1 were verified, observing a score of $2.75 / 5$ in the treatments $\mathrm{T} 0$ and $\mathrm{T} 3$ and a value of $1.38 / 5$ in the Treatment T1.

Table 4: Organoleptic Rating

\begin{tabular}{|c|c|c|c|c|c|c|c|c|c|c|c|c|c|c|c|}
\hline & \multicolumn{12}{|c|}{$\%$ Of milk of Lupinus mutabilis } & \multirow[b]{2}{*}{$\mathrm{H}$} & \multirow[b]{2}{*}{$\mathrm{p}$} & \multirow[b]{2}{*}{ sig } \\
\hline \multirow[t]{2}{*}{ Settings } & 0 & & & $10 \%$ & & & $20 \%$ & & & $30 \%$ & & & & & \\
\hline & $\mathrm{X}$ & D.E & & $\mathrm{X}$ & D.E & & $\mathrm{X}$ & D.E & & $\mathrm{X}$ & D.E & & & & \\
\hline Odor & 3,5 & 0,5 & $\mathrm{~b}$ & 2,0 & 0,8 & $\mathrm{a}$ & 2,0 & 0,5 & $\mathrm{a}$ & 2,1 & 1,3 & $\mathrm{a}$ & 11,64 & 0,0056 & $*$ \\
\hline Color & 2,7 & 1,3 & $\mathrm{a}$ & 2,6 & 1,2 & $\mathrm{a}$ & 3,1 & 0,8 & $\mathrm{a}$ & 2,4 & 1,1 & $\mathrm{a}$ & 2,03 & 0,5351 & ns \\
\hline Flavor & 3, & 1,2 & $\mathrm{a}$ & 3,0 & 1,2 & $\mathrm{a}$ & 2,5 & 0,8 & $\mathrm{a}$ & 2,8 & 1,3 & $\mathrm{a}$ & 1,23 & 0,7224 & ns \\
\hline Texture & 2,6 & 1,2 & $\mathrm{a}$ & 2,8 & 1,6 & $a$ & 3,5 & 1,2 & $\mathrm{a}$ & 2,5 & 1,4 & $\mathrm{a}$ & 2,78 & 0,4061 & $\mathrm{~ns}$ \\
\hline Acidity & 2,1 & 1,1 & $\mathrm{a}$ & 2,3 & 1,4 & $\mathrm{a}$ & 2,3 & 1,2 & $\mathrm{a}$ & 2,4 & 1,5 & $\mathrm{a}$ & 0,11 & 0,989 & $\mathrm{~ns}$ \\
\hline appearance & 2,8 & 1,4 & $\mathrm{~b}$ & 1,4 & 0,7 & $\mathrm{a}$ & 2,3 & 0,9 & $a b$ & 2,8 & 1,0 & $\mathrm{~b}$ & 7,24 & 0,047 & $*$ \\
\hline \multicolumn{16}{|c|}{$\begin{array}{c}\text { E. Estand.: Standard error, * Highly significant statistical difference, } \\
\text { ns: Significant statistical difference }\end{array}$} \\
\hline \multicolumn{16}{|c|}{$\mathrm{P}>0.05$, There are no statistical differences according to ADEVA } \\
\hline \multicolumn{16}{|c|}{ FUENTE: Cortez, C. (2015) } \\
\hline & & & & & & & a de $\mathrm{K}$ & kal W & llis & & & & & & \\
\hline
\end{tabular}

\section{Volume 6 Issue 1, January 2017 www.ijsr.net}




\section{International Journal of Science and Research (IJSR) \\ ISSN (Online): 2319-7064 \\ Index Copernicus Value (2015): 78.96 | Impact Factor (2015): 6.391}

\section{Discussion}

Based on data collected from studies conducted by Kisza and Zbikowski 1975; Bassalik-Chabielska 1989; Mehala and AlKahnal 1989; Sato et al. 1998. We can clearly observe that according to the protein content no significant differences are observed, which indicates that the three products contribute favorably the nutrition of the consumer, in relation to the fat content can be observed the reduction is significant which favors its consumption Since in the milk of Lupinus mutabilis there are tocopherols and Phytosterols that are polyunsaturated fatty acids being very beneficial to health, in terms of carbohydrate content.

We can mention that there is a significant reduction in what constitutes a food suitable for the consumption of people with diabetes

We should also mention that in the absence of lactose content in milk of Lupinus mutabilis is recommended for people with intolerance to this compound disaccharide; But from the technological point of view it is not recommended to exceed $30 \%$ substitution of milk of Lupinus mutabilis since it does not contain casein which affects in the coagulation during the elaboration of the fresh cheese.

Monta Gómez Maritza, Alemán Margarita, Nazate Wilmer 2002, used the milk of Lupinus mutabilis for the elaboration of yogurt and they mention that the milk acts of optimal way diminishing the use of gelatine since it gives a greater density to the yogurt and giving a high yield In processing but that there are lost separating the shell and other components such as alkaloids are lost, in addition that Lupinus mutabilis provides a high protein content without lactose and low in fat being highly recommended its consumption for its high nutritional value.

Liu, 1997 quoted by Chumchuere et al. 2000 mentions that soy and its derivatives as the quesillo, is an excellent source of proteins, essential amino acids and has many uses for human consumption in addition that contains more proteins than meat and three times more Than egg, being a good alternative for the elaboration of foodstuffs by containing vitamins especially of type B1, B2 and folic acid and does not contain lactose providing an alternative of consumption for people who have problems with the absorption of the lactose (IESN 2001).

SUN and BREENE, 1991 indicate that soy milk is low in calcium and sulfur amino acids compared to cow's milk, it is postulated that when using as a traditional substitute for cow's milk, it must be fortified with calcium, vitamins and minerals This is why YACIZI et al., (1997) propose the fortification with calcium of soy milk with a maximum limit of $38 \mathrm{mg} / \mathrm{g}$ of protein.

Mention that soybeans can be used for the elaboration of functional foods such as meat and soybean cake providing a high nutritional value and being an alternative as a substitute for animal meat For vegetarians also mention that by containing vegetable fatty acids can be a contribution in the field of medicine for the prevention of breast cancer and cardiovascular diseases.

Indira Rodríguez, Evelin Saldaña 2009, mention the consumption of delactosed cheeses as functional foods to improve intestinal health and overall health especially in people with problems of lactose assimilation and the benefits of consuming prebiotic bacteria ranging from the prevention of diarrhea to reduction Of cholesterol.

Andrea Cortez, 2015, mentioned that the thesis focused on the development of fresh cheese, not on the microbial effect of Lupinus mutabilis milk on fresh cheese, so I presume that Lupinus mutabilis milk has no microbial effect, The more it is based, the lower the microbial load in the process because each treatment takes into account the necessary hygiene measures.

\section{Conclusions}

Based on the results obtained in the present work, the following conclusions can be made:

1) When partially replacing cow's milk with Lupinus mutabilis milk, it was determined that when $40 \%$ of Lupinus mutabilis milk was added, favorable results were not obtained since Lupinus mutabilis milk does not contain casein, an important component for the production Of fresh cheese.

2) The organoleptic assessment allows us to determine that the treatment most accepted by panelists is the $\mathrm{T} 1$ treatment that has the characteristics most similar to those of traditional fresh cheese

3) The processing process presented a correct management of the hygiene reason why a high number of aerobic mesófilos and of molds were not found.

4) As milk increases Lupinus mutabilis lowers lactose levels, which determines that this product can be consumed by people who are intolerant to this component.

\section{Recommendations}

1)Based on the results obtained in this research, it is possible to recommend the use of Lupinus mutabilis milk in the production of fresh cheese for consumers who have lactose intolerance

2)To investigate further the partial or total replacement of cow's milk by Lupinus mutabilis milk in the manufacture of traditional dairy products

3) Carry out the fresh cheese with the substitution of $10 \%$ of milk of Lupinus mutabilis for having the best organoleptic characteristics and the best cost benefit of the milk treatments of Lupinus mutabilis.

\section{References}

[1] Acebal, M, "Composición y propiedades de la leche y el suero," 2013

[2] Agrocsic, El analisis sensorial en el control y aseguramiento de la calidad de los alimentos, Agrocsic 2-3 2005 1982. (book style) 
[3] Agropecuarias, I. N, "Retrieved from Tecnologias parausus alternativosdel Lupinus mutabilis ," 2011

[4] Alcoser, M., "Esquema del Experimento,", 2014

[5] Alonso, J, "TRATADO DE FITOFARMACOS Y NUTRACEUTICOS,” Buenos Aires: CORPUS 2008

[6] J. Geralds, "Sega Ends Production of Dreamcast," vnunet.com, para. 2, Jan. 31, 2001. [Online]. Available: http://nl1.vnunet.com/news/1116995. [Accessed: Sept. 12, 2004]. (General Internet site)

[7] Alvarado, N, Elaboracion de la Leche de Lupinus mutabilis, http://webcache.googleusercontent.com, 2014.

[8] Arias, L., Análisis Microbiológico de Leche,Quesos y Helados a Base de Lácteos. http://es.scribd.com/doc/6907272/Microbiologia-de-

Alimentos-Analisis-Microbiologico-Leche-y-Derivados, 2013.

[9] Eliezer A. Gandra, M. B., Potencial antimicrobiano y antioxidante de extractos vegetales de romero, hinojo, estragón y orégano, Alimentos: Ciencia, Tecnología e Ingeniería, 24 - 29., 2010.

[10]Fernández, R., Propiedades de las leches vegetales, Alimentaciòn, Fitnes y nutrición, 2015.

[11]Nuñez, B., ). El Ph de la leche, Enciclopedia y Guía Familiar de Alimentación, Nutrición y Dietética, 2013.

[12]LOSADA, M., Google bokks. Retrieved from http://www.bokks.google.com.ec./boks7id=UNraJqwOlq UC\&sorce=gbs_navlinkss, 2014.

\section{Author Profile}

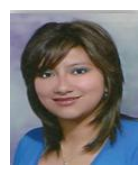

Cortez Andrea graduated in Engineer in Livestock Industry at the Polytechnic Superior School of Chimborazo, Master's Degree in Food Processing at the Agrarian University of Ecuador, Professor of the Quevedo State Technical University at the Faculty of Engineering Sciences

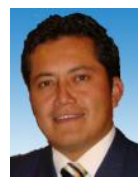

Ruiz Hernan graduated in Engineer in Livestock Industry at the Polytechnic Superior School of Chimborazo, Master in Livestock Industries Mention Meat Industries in High School Polytechnic of Chimborazo

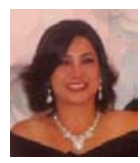

Torres Ruth graduated from Agroindustrial Engineering at Technological University Equinoccial, Master in Safety and Prevention of Work Risks at Universidad Tecnológica Equinoccial, Professor of the Quevedo State Technical University in the Faculty of Engineering Sciences 